\title{
Institutional aspects of development of regional PPP Projects
}

\author{
Svetlana Chudnovskaya ${ }^{1, *}$, Tatiana Vlasova $^{1}$, Mikhail Volkov ${ }^{1}$, Viktoriya Tsvetkova $^{1}$ \\ ${ }^{1}$ Moscow State Region University, 10a, Radio Street, 105005, Moscow, Russia
}

\begin{abstract}
The relevance of research into institutional aspects of public-private partnership (PPP) is evidenced by the continuously increasing role of research-and-technology, information technology, territorial and socioeconomic factors of influence on the development and implementation of regional PPP projects aimed at improving social welfare and accelerating the rate of socioeconomic development of Russia's regions. Systemic impact of technical, technological, territorial and socioeconomic factors stipulates the need for the development of institutional environment of PPPs, which implies taking measures for protecting private investments and interests of private investors. This impact also predetermines the necessity to improve the currently existing institutional models of informational-legal base that ensure integration processes of managing PPP projects, with taking into consideration of regional differences and excess investment risks. In this regard, the present paper is aimed at detecting problems of development of PPP's institutional environment at the regional level. The solution of these problems will allow elaborating models of institutional environment having integrated legal and regulatory framework, transparent and intelligible procedures and standing orders that are necessary when implementing complex socioeconomic projects of public importance for the development of regions. The authors of the paper have defined the role of institutional environment of public-private partnership (PPP) and municipal public-private partnership (MPPP) in the development of a region. The paper provides the results of generalized analysis of factors of development of institutional environment and regulatory-legal framework at the regional level. There were defined problems entailing the performance risks concerning the support of regional projects by public partners and risks of integrated models of interagency interaction at the stages of elaboration, selection and making decisions on implementing PPP and MPPP projects, performing measures of control, maintenance, monitoring and maintaining a register of PPP projects. The results of the research given in the paper are of applied importance for both academicians and practical workers, especially in using the assessments of a development level of institutional environment and legal framework when preparing or implementing projects on improving a region.
\end{abstract}

\section{Introduction}

A study of the development of public-private partnerships in various regions of Russia shows that the most important factors influencing the depth and level of development of public-private partnerships are the regional features of social and economic development: transport and socio-economic infrastructure, sectoral characteristics and investment attractiveness of regional projects, investment risks of private partners, level of

\footnotetext{
${ }^{*}$ Corresponding author: svetlana45-11@yandex.ru
} 
development of regional legislation in the field of public-private partnerships (A.N. Savrukov, N.T. Savrukov, E. A. Kozlovskaya 2018., Nicholas Bloom., John Van Reenen., Williams Heidi. 2019). But, in addition to these factors, the modern socio-economic development of many Russian regions, especially the regions of Siberia and the Far East, is still influenced by the State concept of the development and deployment of productive forces used in the past (which is brightly reflected in the use of classifications «mining» regions, regions «donors» etc.). In this regard, public and municipal-private partnerships in the implementation of regional projects have different social and economic bases, shaped by the historical imbalances and, as a result, different development potential. In regions with a high concentration of fuel and energy industries, PPP efficiency provides a high potential for development in the donor region (Khanty-Mansiysk Autonomous Region). But it should be noted that this impact, despite the economic power of industrial corporations of fuel and energy complex, cannot be lasting. Dependence on the oil and gas prices plays the role of multiplier in objectively increasing production and management expenses, the high cost of technological losses, the orientation of corporations towards short-term goals (T.I. Vlasova, S.N. Chudnovskaya 2018).

Global and regional factors have an integrated impact on the implementation of publicly and socially significant regional public-private partnership projects in the field of health care, education, recycling and treatment of domestic and industrial waste, communications and telecommunications, mass catering as well as programs to improve the quality and accessibility of social and cultural services for the population (Boyarintsev B.I., Lanz V.R. 2019, Borschevsky G.A 2019).

An analysis of the development of the institutional environment for PPPs shows that improvements in the legal and regulatory framework provide some impetus for growth. The National Centre for Public-Private Partnerships proposes new indicators for its evaluation in the constituent entities of the Russian Federation in order to assess the level of the institutional environment of PPPs in the regions. It is suggested to use integrated indicators in the constituent entities of the Russian Federation as targets for the institutional environment and the legal and regulatory framework for PPPs, including infrastructure planning and interdepartmental cooperation, subsidies, establishment of a PPP management system with information openness. The assessment and estimation of critical factors at the level of advancement of the institutional environment of PPP is being improved. Thus, for the rating of factor «Experience of project implementation», it is recommended using the stages of implementation and the total amount of investment, the system of coefficients of sectoral differentiation is expanded, appraisement of the project's relevance is introduced. Numerous procedural issues arise that require regulation at the legislative level when structuring investment projects according to PPP principles. (A.A. Rementsov 2017)

New target models for the development of the institutional environment and the legal and regulatory framework of PPPs are proposed (M.V. Tkachenko «On a new methodology for assessing the level of PPP development in the constituent entities of the Russian Federation», Presentation of the Infrastructure Congress "Russian PPP Week 2019"). The National PPP Centre proposes to implement the second version of the Regional PPP Standard (M.V. Tkachenko «On a new methodology for assessing the level of PPP development in the constituent entities of the Russian Federation», Presentation materials of the Infrastructure Congress "Russian PPP Week 2019"; Soboleva O., Burtseva T., Barmina E., Ganebnykh E., and Tokareva P. Methodology of Maltivariative Statistical Analysis in Evaluating the Factors of Region's Innovative Activity).

A study on improvement of the institutional and legal environment for public-private partnerships in the regions pinpointed the following challenges:

- different levels of social-economic potential of the regions and local approaches to the development of institutional environment and standards result in various legal and 
regulatory framework in different regions, which makes it complicated to assess and compare institutional environment and hinders private investments and efficient implementation of PPP and MPPP projects;

- shift in focus on structuring quality of projects, when assessing them, creates new demands for tackling problems with proof of ownership, inter-budget participation, loanbased funding, distribution of risks that put a spoke in private investors' wheel to fully use PPP tools in regions with hard socio-economic conditions, low and average development level of institutional environment.

- to assess the impact of the state of the institutional environment and (or) determine the directions of its development, it is necessary to take into account the obligations risks of the municipal public-private partnerships arising from the incomplete implementation of the regional PPP standard or the imperfection presented in it of the legal framework.

The solution of the problems identified makes it possible to define the directions of development of the institutional environment with an integrated legal and regulatory framework, understandable and open rules and procedures for the implementation of different levels of complexity economic and socially significant PPP and MPPP projects in the region.

Goal of the study is to identify factors and issues in the development of the institutional environment and the legal and regulatory framework for public and municipal-private partnerships in the changing socio-economic conditions of the region and areas for improving regulatory effectiveness of regional PPP and MPPP projects.

\section{Materials and Methods}

The study used the following: analysis and systematization of global and regional factors in the development of the institutional environment and the regulatory framework of public and municipal-private partnerships in the regions of Russia; a synthesis of approaches (strategies) and indicators for assessing the development of the institutional environment and the regulatory framework of public and municipal-private partnerships; a comparative analysis of the impact of indicators for assessing the development of the institutional environment and the regulatory framework of public-private partnerships on the effectiveness of the development, study, decision-making on implementation, monitoring, supervision, monitoring and maintaining the register of projects; system analysis of the conditions for attracting private investors; a comparative analysis of the results of the implementation of public-private partnership projects in the regions of Russia as well as the institutional environment and the regulatory framework of public and municipal-private partnerships created in the regions.

A study of the development of public-private partnerships in Russian regions with various social and economic level shows that the most important factors influencing the depth and level of development of public-private partnerships are the regional features of social and economic development: transport and socio-economic infrastructure, sectoral characteristics and investment attractiveness of regional projects, investment risks of private partners, level of development of regional legislation in the field of public-private partnerships (A.N. Savrukov, N.T. Savrukov, E. A. Kozlovskaya 2018., Nicholas Bloom., John Van Reenen., Williams Heidi. 2019).

It should be noted that the regional features of public-private partnerships are closely interconnected with the socio-economic characteristics of Russia. The power of industrial corporations in the regions of the fuel and energy complex affects all spheres of life. But this influence depends on technological breakthroughs, related to overcoming decades-old production problems, management and territorial deployment of productive forces will continue to decline in the near future. The decline in regional dependence on the success of 
the extractive industries is also due to the decline in production efficiency in industrial corporations operating in different regions of Russia. (T.I. Vlasova, S.N. Chudnovskaya 2018.). Under the current conditions, there is still a large share of public-private partnership projects of regional road infrastructure. Though, the tendency when more and more regions implement a significant number of projects in the field of healthcare, social infrastructure, housing and utilities sector and introduction of new information technologies is already noticeable. Increasing investments in complex socially significant infrastructure projects is carried out by the Moscow, Samara, Tambov regions, St. Petersburg, the Khanty-Mansiysk and Yamalo-Nenets Autonomous Districts and other regions of Russia (Presentation materials of the Infrastructure Congress "Russian PPP Week 2019"). Results of the research by V.A. Tsvetkov, K.H. Zoidov, A.A. Medkov 2016, 2017, obtained in the process of analyzing public-private partnerships during the creation of joint ventures in the transport and transit network of Russia, and, results of the research by V.A. Barinova, S.P. Zemtsov, $\mathrm{Yu}$.V. Tsareva 2018., obtained in the process of analyzing the relationships between entrepreneurship and institutions at the regional level in Russia, confirm the hypothesis that there are systemic relationships between the level of development of the institutional environment of public-private partnership and the level of socio-economic development of the region. The research of G.A. Borschevsky 2019 confirm this hypothesis: the relationship between the level of development of the institutional environment is fixed with an increase in the number of new projects, an increase in the trust of participants in publicprivate partnerships and, in general, with an increase in the volume of private investments in regions with positive experience in implementing regional projects.

The use of public-private partnerships (PPPs) in the most important areas of regional life drastically enhances the potential for regional development, and has an integrated effect on the success of socially significant regional public-private partnership projects in the areas of healthcare, education, recycling and treatment of domestic and industrial waste, communications and telecommunications, consumer services, mass catering and others (B.I. Boyarintsev, V.R. Lants 2019., G.A. Borschevsky 2019). The role of the institutional environment of PPP in the implementation of such projects is reflected in Fig. 1.

Along with the success of PPPs, the development of the regulatory framework of the regions stumbles into barriers of public-private partnerships (Pshenitsyna E.I., Sigarev A.V. 2018.). Studies found that one of the common barriers to the development of the institutional environment of PPPs in the constituent entities of the Russian Federation is formed as a result of the application of different approaches (strategies) in regulating the scope of PPPs at the regional level. According to the criterion of the development level of the regulatory framework in the region, it is possible to identify the regions and constituent entities of the Russian Federation that use the existing regional legislative framework in the field of PPP after the adoption of the Federal Law on PPP (St. Petersburg, Republic of Tatarstan); regions that directly apply federal legislation in the area (Moscow, Yaroslavl, Tula regions) and regions that use, along with federal legislation, developed and adopted regional regulations on the most important aspects of municipal-private partnerships, which include interagency cooperation (Voronezh, Kaluga regions and other). Clearing the way for interagency interactions creates additional opportunities for "leveling" the legal framework of PPPs in the constituent entities of the Russian Federation (Article 47 of the Federal Law on PPPs, fixing the need for alignment, regulatory legal acts of constituent entities of the Russian Federation, legal acts of municipalities in the field of public-private and municipal public-private partnership and bringing it into line with the provisions of the Federal Law on PPP until January 1, 2025). 


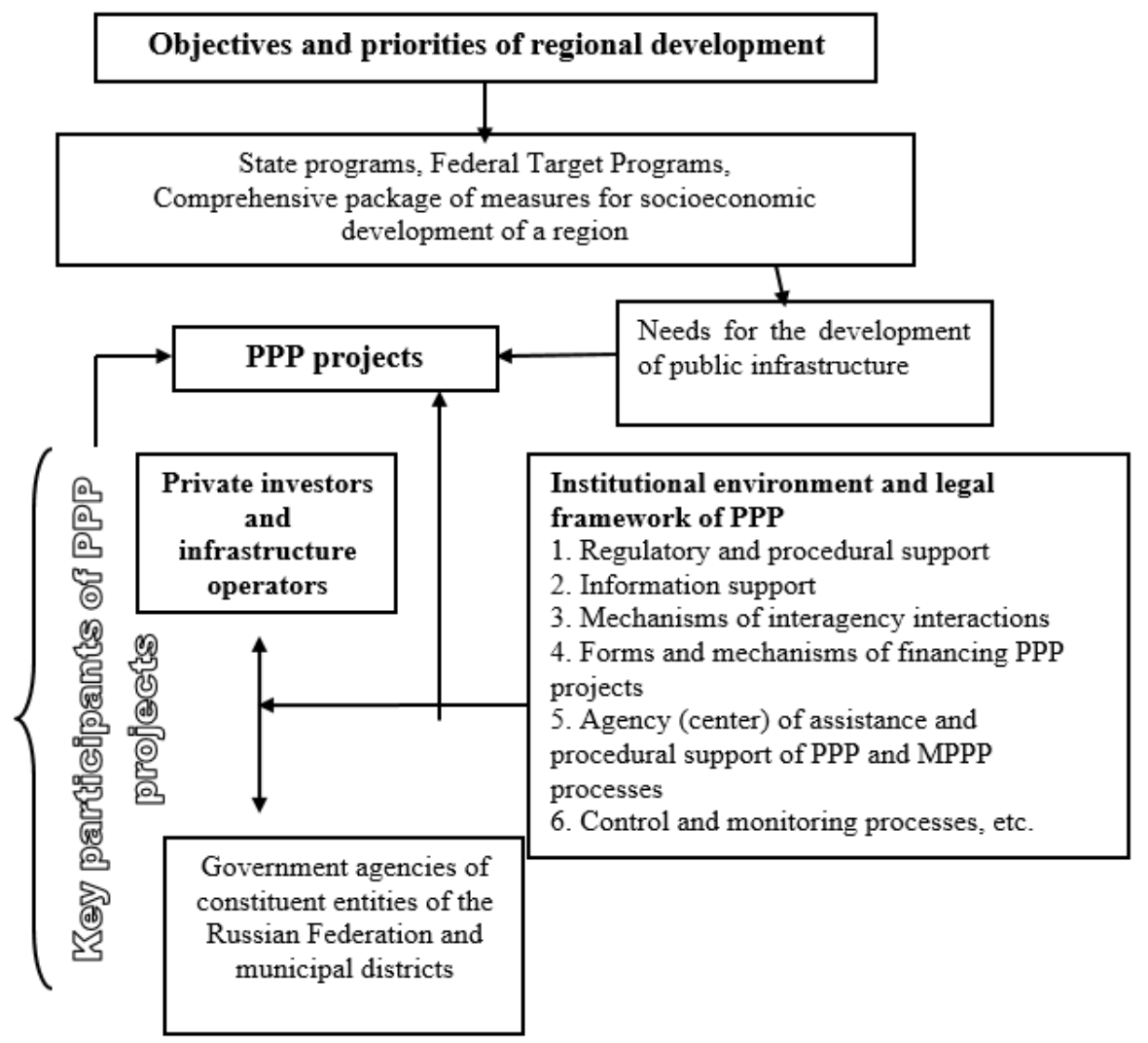

Fig. 1. The role of the institutional environment of public-private (municipal public-private) partnership in the development of the region.

Peculiar obstructions that are faced during the development of regulatory framework of PPPs and MPPPs at the regional level characterize the regional specifics. For instance, the absence (until now) in the Russian Federation of a correct methodology for assessing the presence of public infrastructure facilities in territories. The lack of a methodology entails difficulties and errors when defining the actual demand for certain public infrastructure facilities of a constituent entity of the Russian Federation or of a certain municipality. This obstructs the compilation of a list of existing facilities that have market potential (are in demand), and of those that require modernization, in accordance with the regional PPP standard. The list of modernization facilities (for example, social infrastructure) as PPP or MPPP objects enlarges the choice of facilities and projects for a private investor.

The analysis of a state of institutional environment of PPPs in constituent entities of the Russian Federation showed that now in many regions the regulatory framework is being amended in accordance with regional PPP standards. This enables a fact-based assessment of the actual situation of PPPs and MPPPs in a region and an adequate comparative analysis of the development of a regional system of PPPs and MPPPs. In general, the determinants of PPP development level in a region are the following: regional differentiation, distance barriers, industry specialization of certain constituent entities in mining, industrial production or agriculture, their geographical location, population, investment attractiveness, opportunities and features of the formation of regional and local budgets. Thus, different regions have different levels of PPP development. Table 1 presents the correlation between 
the development level of the institutional environment of the regions and the effectiveness of implementing PPP/MPPP projects in 2018.

It should be noted that development of institutional environment and regulatory framework of public-private partnerships is largely affected by the population's potential in a particular region in general and by human potential in the field of PPP in particular, especially at the stage of project support. Human factor affects the results of interagency interactions at all the stages of managing regional PPP and MPP projects: elaboration, monitoring, making decisions on their implementation, supervision and monitoring of ongoing regional projects. It also affects the cooperation with municipal authorities when preparing and implementing concession projects (in the field of heat supply, water supply and sanitation). Nevertheless, the study revealed that there is a lack of specialists in this field in many regions. In this regard, organization of a system of advanced training and retraining of specialists in the field of PPPs is becoming an important area of development of institutional environment of PPPs in the regions of the Russian Federations.

Table 1. Correlation between the level of development of the institutional environment and the state of PPPs/MPPPs in the regions.

\begin{tabular}{|c|c|c|c|c|}
\hline \multicolumn{5}{|c|}{$\begin{array}{l}\text { Leading regions of Russia in the level of PPP(Compiled according to the data of independent } \\
\text { nonprofit organization National PPP Center) development }\end{array}$} \\
\hline $\begin{array}{l}\text { Constituent } \\
\text { entity of the } \\
\text { Russian } \\
\text { Federation }\end{array}$ & $\begin{array}{lr}\text { The main economic } \\
\text { activities in the } \\
\text { structure of gross } \\
\text { regional product }\end{array}$ & $\begin{array}{l}\text { Amount of } \\
\text { registered } \\
\text { PPP } \\
\text { projects }\end{array}$ & $\begin{array}{l}\text { Amount of } \\
\text { private } \\
\text { investment in } \\
\text { registered PPP } \\
\text { projects } \\
\text { (billion rubles) }\end{array}$ & $\begin{array}{l}\text { Institutional } \\
\text { environment } \\
\text { and legal } \\
\text { framework }\end{array}$ \\
\hline Moscow & $\begin{array}{l}\text { Wholesaling and retail } \\
\text { Process manufacturing }\end{array}$ & 43 & 550.5 & 12.2 \\
\hline Saint-Petersburg & $\begin{array}{l}\text { Wholesaling and retail } \\
\text { Process manufacturing }\end{array}$ & 35 & 318.8 & 12.2 \\
\hline $\begin{array}{l}\text { The Moscow } \\
\text { region }\end{array}$ & $\begin{array}{l}\text { Wholesaling and retail } \\
\text { Process manufacturing }\end{array}$ & 40 & 74.1 & 11.8 \\
\hline $\begin{array}{l}\text { Republic of } \\
\text { Bashkortostan }\end{array}$ & Process manufacturing & 44 & 16.6 & 12.2 \\
\hline Samara Region & Process manufacturing & 48 & 32.5 & 12.2 \\
\hline $\begin{array}{l}\text { Khanty-Mansi } \\
\text { Autonomous } \\
\text { Okrug - Yugra }\end{array}$ & $\begin{array}{l}\text { Extraction of mineral } \\
\text { resources }\end{array}$ & 36 & 34.8 & 11.7 \\
\hline Oryol Region & $\begin{array}{l}\text { Wholesaling and retail } \\
\text { Agriculture }\end{array}$ & 7 & 0.4 & 4.4 \\
\hline Bryansk region & $\begin{array}{l}\text { Сельское хозяйство } \\
\text { Wholesaling and retail } \\
\text { Process manufacturing }\end{array}$ & 2 & 0.01 & 5.8 \\
\hline Tyva Republic & $\begin{array}{l}\text { Extraction of mineral } \\
\text { resources }\end{array}$ & 4 & 1 & 4.4 \\
\hline $\begin{array}{l}\text { Republic of } \\
\text { Ingushetia }\end{array}$ & $\begin{array}{l}\text { Public administration and } \\
\text { defense; } \\
\text { social welfare }\end{array}$ & 2 & 0.4 & 3.8 \\
\hline $\begin{array}{l}\text { Republic of } \\
\text { North Ossetia - } \\
\text { Alania }\end{array}$ & $\begin{array}{l}\text { Public administration and } \\
\text { defense; } \\
\text { social welfare } \\
\text { wholesaling and retail }\end{array}$ & 1 & 0.4 & 3.9 \\
\hline $\begin{array}{ll}\text { Republic } \\
\text { Kalmykia }\end{array}$ & Agriculture & 0 & 0 & 4.0 \\
\hline
\end{tabular}


The development of institutional environment and the legal framework of PPPs and MPPPs is fraught with uncertainties and risks for private investors and for the implementation of PPP projects. One of the main features of PPPs, which is also their advantage over other ways of implementing infrastructural and social projects, is the mechanism for sharing risks between the parties of PPP. (M. Y. Sokolov, S.V. Maslova, 2013) Experience evidences that the improvement and development (change) of the legal framework of PPPs and MPPPs is often fraught with deficiencies and lack of guidelines for assessing standards, calculating coefficients, rating or with difficulties of taking into account the specifics and features of regional projects. To this day, there are no effective tools and methods for a comprehensive assessment of numerous risks that arise when projects are launched as parts of public-private partnership models (A.A. Rementsov, 2017) Such deficiencies entail the most common regulatory risks or risks directly related to changes in law. The difficulty of the process of securing the liability of PPP's and MPPP's parties, and the limited rules for choosing the applicable law and jurisdictional body, form contractual risks, which are complicated and diverse because of the diversity of contracts (supply contract, lease contract, etc.). Incomplete fulfillment of a regional PPP standard leads to the arising of various risks for implementing plans of region's social infrastructure development on the basis of PPP projects. Within the process of implementing regional MPPP projects regarding education and healthcare, there emerged the risks of non-public legal relations related to the use of intellectual property. It is important that the risks of the legal framework emerged entailed the enhancement of project risks.

If ignoring risks of the legal framework, the following threats may occur: the loss of control over PPP and MPPP (illegal actions of shareholders, bankruptcy), claims of counterparties, restriction of authority of governing bodies or revocation of their decisions, restriction of power to manage or eject property and assets, claims of state or municipal government agencies, risk of partnership liquidation. It also may be associated with the loss of reputation of a private investor or PPP/MPPP as a whole.

The study on interconnection of the risks of legal framework development and the effectiveness of implementing regional PPP and MPPP projects allows determining the most common risk groups and consequences of these risks (Table 2).

Table 2. Risks of institutional environment of regional PPP and MPPP projects.

\begin{tabular}{|l|l|l|}
\hline № & \multicolumn{1}{|c|}{ Risk group } & \multicolumn{1}{c|}{ Possible risks } \\
\hline 1. & $\begin{array}{l}\text { Risks of drawbacks } \\
\text { of the regulatory } \\
\text { and } \\
\text { framework legal }\end{array}$ & $\begin{array}{l}\text { invalidation of certain provisions of regulatory legal acts of the } \\
\text { constituent entities of the Russian Federation and, as well as of } \\
\text { agreements made in accordance with these norms; } \\
\text { re-qualification of a PPP agreement into another form by court } \\
\text { decision, due to exceeding the terms of budget planning, if the } \\
\text { project provides for payment in installments to a private investor; } \\
\text { increase in the time and complexity of the process of making a } \\
\text { decision on the conclusion of a PPP agreement; } \\
\text { termination or reduction of project financing in case of exceeding } \\
\text { the period of validity of budgetary obligations; } \\
\text { the emergence of conflict situations due to the conflicting interests } \\
\text { of federal, regional and local authorities; } \\
\text { a non-transparent procedure of government control over the } \\
\text { implementation of a PPP project; } \\
\text { an increase in the overall terms for a project implementation; } \\
\text { improper fulfillment of the contract by a public partner. }\end{array}$ \\
\hline 2. & $\begin{array}{l}\text { Risks of managing a } \\
\text { regional project }\end{array}$ & $\begin{array}{l}\text { loss of implementation time, of financial and material resources } \\
\text { due to lack of experience and lack of experts having special } \\
\text { qualification in the field of PPPs; } \\
\text { inappropriate (unfair) distribution of competencies and }\end{array}$ \\
\hline
\end{tabular}




\begin{tabular}{|l|l|l|}
\hline \multirow{1}{*}{} & & $\begin{array}{l}\text { responsibilities between public and private partners leads to loss of } \\
\text { manageability; } \\
\text { non-transparent procedure for consideration of initiated projects, } \\
\text { loss of the reputation of the MPPPs; } \\
\text { lack of a coherent policy in managing the PPP sector in the region } \\
\text { leads to financial losses and irrational investments; } \\
\text { stemmed from corruption, the loss of power to regulate state } \\
\text { institutions and the violation of the antitrust law by participants of } \\
\text { PPP and MPPP projects entail the distrust of institutions; } \\
\text { destruction of mechanisms of state support for PPP projects. }\end{array}$ \\
\hline 3. & $\begin{array}{l}\text { Risks of integration } \\
\text { of institutional } \\
\text { environment and } \\
\text { regulatory and legal } \\
\text { framework }\end{array}$ & $\begin{array}{l}\text { deficit of budget financing of public infrastructure development } \\
\text { projects; } \\
\text { decrease in general investment attractiveness of a region; } \\
\text { slowdown in the development of territories and facilities of social } \\
\text { infrastructure, in comparison with other regions; } \\
\text { the impossibility of increasing the cost-effectiveness of the } \\
\text { implementation of regional infrastructure projects; } \\
\text { limiting the possibilities of attracting innovation and innovative } \\
\text { technologies in the region's economy. }\end{array}$ \\
\hline 4. & $\begin{array}{l}\text { Risks of private } \\
\text { investors }\end{array}$ & $\begin{array}{l}\text { loss of interest of partners in the implementation of a PPP or } \\
\text { MPPP project; } \\
\text { the inability of a private investor to initiate a PPP or MPPP } \\
\text { project, and to propose conditions for its implementation that give } \\
\text { an advantage over other bidders (existing practice in some } \\
\text { countries); } \\
\text { decrease in investment attractiveness of PPPs and MPPPs among } \\
\text { private investors; } \\
\text { decrease in investor confidence in the long-term cooperation with } \\
\text { a public partner; } \\
\text { a decrease in profitability and an increase in the payback period } \\
\text { due to the lack of tax incentives, soft loans and other incentive } \\
\text { measures for a private investor of PPP or MPPP. }\end{array}$ \\
\hline
\end{tabular}

Consideration of preventive measures or development of mechanisms for managing the risks detected, while improving the institutional environment and legal framework of PPPs and MPPPs or while implementing national and regional PPP projects, will contribute to the development of the region's social infrastructure for the purpose of improving the population's welfare.

\section{Results}

1. The existing socioeconomic potentials of different constituent entities of the Russian Federation and application of regional approaches to the development of institutional environment and the legal and regulatory framework of PPPs and MPPPs, entail the elaboration of regional regulatory frameworks of different compositions and cause the existence of different levels of development of the institutional environment. In this regard, the development of the regulatory framework of the regions faces certain PPP barriers of both general and particular character, which obstructs the comparability and assessment of levels of development of the institutional environment and creates barriers hampering the attraction of private investment and the implementation of regional PPP and MPPP projects.

Researches into the problem posed showed that the imbalance in the development of public-private and municipal public-private partnerships in the regions is caused by historically formed difference in regions' levels of socio-economic development due to 
their industry specializations, budgetary capacity, investment attractiveness of regional projects and high investment risks and barriers obstructing the attraction of private investors by regions of difficult socioeconomic situation and medium or low level of development of their institutional environment. The human potential of a region plays a large role in the development of institutional environment and regulatory framework of public-private partnerships. Personnel qualifications should be taken into account when assessing the level of development of institutional environment on the basis of calculation the rating.

2. The emphasis is shifted to the quality of structuring the projects during their evaluation, which creates new requirements for solving problems, involving the determination of the title of ownership, inter-budgetary participation, availability of borrowed financing, risk sharing, which puts barriers in using of PPP instruments by private investors in regions with difficult socioeconomic conditions, medium or low level of development of the institutional environment.

Studies on changes in the regulatory framework of PPPs in the regions have shown that general and special barriers of public-private partnership are formed by systemic violations in the regulatory framework of PPPs and MPPPs in a region. Removing the most common barriers for interagency interactions opens up additional opportunities for leveling the legal framework of PPPs in constituent entities of the Russian Federation. With the development of the regional legal framework for PPP and MPPP, it is necessary to harmonize regional legislation in accordance with the adopted regional standards of PPPs.

3. To assess the impact of the state of the institutional environment and (or) determine the directions of its development, it is necessary to take into account the performance risks of PPPs and MPPPs arising when a regional PPP standard is implemented incompletely or when the legal framework presented in this standard has drawbacks.

The study on interconnection of the risks of legal framework development and the effectiveness of the implementing regional PPP and MPPP projects allowed distinguishing the most common risk groups and consequences of those risks. Ignoring the risks concerning the regulatory framework provokes the loss of control over PPP and MPPP (illegal actions of shareholders, bankruptcy), claims of counterparties, restriction of authority of governing bodies or revocation of their decisions, restriction of power to manage or eject property and assets, claims of state or municipal government agencies, risk of partnership liquidation. It also may be associated with the loss of reputation of a private investor or PPP/MPPP as a whole.

\section{Discussion}

The research results presented in the article include the following discussion questions:

The legal framework is a core system element of institutional environment of publicprivate partnerships. Its development is one of the strategic goals of state and municipal government in the constituent entities of the Russian Federation. In this regard, the following aspects may become the relevant subjects of further research and discussion:

models and mechanisms of strategic planning for regional development, taking into account the integrity, consistency and balance of the regulatory and legal framework for the implementation of regional PPP and MPPP projects;

Change of models of improving the institutional environment and the regulatory and legal framework of public-private partnerships in the regions of Russia, including the directions for development of the institutional environment and the legal framework of public-private partnerships to dampen the impact of global challenges.

The problems of increasing the efficiency of implementing complex regional projects of social importance remain a significant aspect of the scientific discourse. This refers to 
implementations with interagency cooperation at the stages of the life cycle of a project, the efficiency of which is increased through the development of institutional environment and regulatory framework of public-private partnerships at the regional level.

\section{Conclusions}

The researches into the development of institutional environment and regulatory and legal framework of PPPs in the regions of Russia are driven by the increasing role of researchand-technology, information technology, territorial and socioeconomic factors influencing the development and implementation of regional public-private partnership projects aimed at improving welfare and accelerating socioeconomic development of Russian regions. The paper has presented the results of the studies on the most significant issues: determination of systemic factors of influence on the area and depth of development of institutional environment and regulatory and legal framework of PPPs in the regions; detection of imbalances, barriers and directions for improving the legal framework of PPPs; assessment of the role of changes in the regulatory framework of PPPs in the regions and consideration of performance risks of PPPs and MPPPs that arise from the incomplete fulfillment of regional PPP standards or from the drawbacks of the regulatory framework presented in these standards. The carried out studies open up new opportunities for the development of regulatory framework and the creation of favorable institutional environment of PPPs and MPPPs in the regions of the Russian Federation.

\section{References}

1. Ye.I. Pshenitsyna, A.V. Sigarev, Mirovaya ekonomika: problemy bezopasnosti 3, 54$56(2018)$

2. T.I. Vlasova, S.N. Chudnovskaya, O.L. Chulanova, International Scientific Conference "Global Challenges and Prospects of the Modern Economic Development GCPMED (2018)

3. V.A. Tsvetkov, K.KH. Zoidov, A.A. Medkov, Ekonomicheskaya nauka sovremennoy Rossii 4(75), 79-91 (2016)

4. V.A. Tsvetkov, KKH. Zoidov, A.A. Medkov, Ekonomicheskaya nauka sovremennoy Rossii 1(76), 61-74 (2017)

5. B.I. Boyarintsev, V.R. Lants, Ekonomicheskaya nauka sovremennoy Rossii 4(87), 7084 (2019)

6. G.A. Borshchevskiy, Voprosy gosudarstvennogo i munitsipal'nogo upravleniya 4, 7-21 (2018)

7. A. Mottaeva, E3S Web of Conferences 110, 02164 (2019) doi.org/10.1051/e3sconf $/ 201911002164$

8. G.A. Borshchevskiy, Voprosy ekonomiki 2, 134-157 (2019)

9. N. Blum, Y. Van Reyenen, K. Uil'yams, Voprosy ekonomiki 10, 5-31 (2019)

10. V.A. Barinova, S.P. Zemtsov, Y.V. Tsareva, Voprosy ekonomiki 6, 92-116 (2018)

11. A.V. Bataev, A.A. Gorovoy, A.B. Mottaeva, Proceedings of the 32nd International Business Information Management Association Conference, IBIMA 2018 - Vision 2020, 102-114 (2018)

12. M.V. Tkachenko, «O novoy metodike otsenki urovnya razvitiya GCHP v sub"yektakh $R F »$, https://p3week.ru/images/2019/1.pdf 
13. V.V. Pereverzeva, T.V. Yur'yeva, Regional'naya ekonomika i upravleniye: elektronnyy nauchnyy zhurnal 1(53), $5309 \quad$ (2018) ISSN 199-2645 https:/eeeregion.ru/article/5309/

14. Prezentatsionnyye materialy Infrastrukturnogo kongressa "Rossiyskaya nedelya GCHP 2019", https://www.p3week.ru/forum-2019/prezentatsii

15. O. Soboleva, T. Burtseva, E. Barmina, E. Ganebnykh, P. Tokareva, Overcoming Uncertainty of Institutional Environment as a Tool of Global Crisis Management, Contribution to Economics, 565-574 (2017) DOI: 10.1007/978-3-319-60696-5_71

16. M.Y. Sokolov, S.V. Maslova, Vestnik S.-Peterb. un-ta. Ser. Menedzhment 4, 100-124 (2013)

17. A.A. Rementsov, Sbornik nauchnykh trudov Moskovskogo avtomobil'nodorozhnogo gosudarstvennogo tekhnicheskogo universiteta (MADI) 19, 71-78 (2013)

18. V. Holodkova, A. Mottaeva, T. Pokrovskaya, E3S Web of Conferences 164, 11043 (2020) https://doi.org/10.1051/e3sconf /202016411043 